\title{
19. The Role of Post-Disaster Institutions in Recovery and Resilience: A comparative study of three recent disasters
}

\author{
James Smart
}

Dealing with natural disasters and their after-effects is among the most difficult tasks governments face. Their harm is pervasive, affecting the financial, social, environmental and human welfare of a country. Managing them often requires coordination between local authorities, businesses, neighbourhood groups and volunteer organisations; but effective management can reduce a disaster's longterm impact.

Governments are concerned with four areas of disaster management, commonly known as the four rs. First, they can reduce societal vulnerability and build resilience through reduction of known risks. Second, readiness is established by building and maintaining capability. Third, these capabilities are marshalled to respond to immediate human needs. Fourth, recovery alleviates immediate societal suffering and improves citizens' long-term prospects by building resilience against future disasters.

This chapter places its focus on the fourth area, recovery and resilience, but an effective recovery owes much to the other areas. Good institutions provide the adaptive capacity that lets communities recover from natural disasters, which is particularly clear when three natural disasters in Australia and New Zealand are reviewed

- Victoria's bushfires in 2009

- Queensland's flooding from 2010 to 2011

- Canterbury's earthquakes from 2010.

These cases demonstrate the importance of flexible management, evidence of institutional learning before and after disasters, the role of community engagement, response to insurance issues and the building of resilience. ${ }^{1}$

1 The full working paper on which this chapter is based, including all references, is available on the Institute of Governance and Policy Studies website: <http://igps.victoria.ac.nz/publications/publications/show/334>. 


\section{Why Disaster Response Matters}

Effective government-led responses often require changes to service delivery and the agencies that deliver them. Existing agencies may be improperly equipped for the tasks that confront them, but implementing changes can take time. Governments unable to respond with the swiftness demanded by citizens can quickly increase societal uncertainty and pessimism. Individuals and businesses may leave the area and financial intermediaries may no longer provide insurance and loans. Declining institutional quality presents greater challenges to governments already unable to drive the recovery process. Changes to those institutions that reinforce community capacity are vital to restore functionality. They should be able to learn from their operational environment, integrate experience and adapt accordingly.

Disasters are exacerbated by policy failure (Birkland 2006). Retrospective inquiries that examine policy choices during disaster response are often instructive, but may also encourage catharsis and relieve perceived injustice among affected people (Bovens 2007). If their recommendations are taken seriously, lessons learned can inform community decision-making during recovery and reduce the effects of future disasters.

As with other crises, optimising the level of resources for disaster recovery is hard. Physical destruction and its proportionality to the economy are unhelpful as metrics to policymakers. Two dynamics are important in the short run. First, capital stock is usually required to produce goods and services. Output will be lower if capital is destroyed, though rebuilding capital will increase output. The net effect of these dynamics is ambiguous; their timing will differ.

Reconstruction is likely to be uneven and much delayed after the initial loss. The mixture of outputs will differ, as seen in labour markets. A destroyed bakery will be unable to produce bread, but may employ a builder to replace its building. This sudden change in the required skill mix could push the economy up against structural limitations, such as the number of trained builders.

The economic impact of disasters is hard to predict during the event, with two competing narratives. Medium-term growth could be lower if structural limits to reconstruction are reached, and if a disaster increases the perceived risk of investing. Medium-term growth could be higher if new capital is superior in quality to old - one prevailing effect in climatic disaster recovery (Skidmore and Toya 2002). On average, ambiguity appears to triumph. Carvallo et al. (2011) find no significant effect on the long-run economic growth of disaster-affected countries.

Most important in this analysis are the human costs, both direct and indirect. The scale and effectiveness of the response have long-term implications for recovery. Seventeen years after Hurricane Iniki hit the Hawaiian island of 
Kauai in 1992, the island's population had not recovered from post-disaster emigration (Coffman and Noy 2009). The fiscal cost of reconstruction borne by governments can lead to major challenges beyond the immediate disaster time frame, particularly if pre-disaster debt is high and capital flight is a genuine risk (Noy 2009). Governments facing these issues may not have the capacity to help communities recover.

Major disasters often result in high stock costs, giving insurance an important recovery role. Insurers may assume that the risk of a high-cost event in the near future is very low but the probability of a disaster is difficult to integrate into actuarial models. Individual destructive events expected to occur with a very low probability impose high, near-simultaneous costs after a disaster. The concurrent timing of these tail events often results in higher than anticipated losses for insurance companies, risking their solvency (Kousky and Cooke 2009).

Ideally, insurance markets help smooth financial costs over a lifetime and improve individual welfare; so individuals who neglect to take out insurance will face relatively higher costs after a disaster. Governments may be tempted to intervene through direct assistance, but some individuals may see such assistance as a quasi-permanent replacement for private insurance. Insurance take-up could be discouraged and dependency on the state would growbehaviour known as moral hazard.

Reconciling the desire to assist risk-takers and the cost of moral hazard is a Samaritan's dilemma. Complex recovery efforts frequently highlight a lack of consensus on values (Hischemoller and Hoppe 1996). It is not clear whether the immediate suffering of citizens is a greater issue than future welfare loss created by moral hazard. These problems demand political solutions, but building consensus requires time. Governments may be unwilling or unable to provide that time, to the detriment of new social rules and expectations that develop.

\section{Responses in Victoria, Queensland and New Zealand}

Australia and New Zealand are both developed economies, sharing a British heritage with similar political and legal institutions, most notably the Westminster parliamentary system; however, their constitutions have important differences. Australia's provides defined roles and responsibilities for Federal and State governments, while local governments provide a third tier of designated responsibilities and roles during disasters. New Zealand has no level between central and local (or regional) government. Local governments raise a modest level of revenue, mostly through property tax, concentrating most of New Zealand's disaster response capacity in Wellington. 
Disasters have affected both countries since 2009. Bushfires burned across Victoria for more than a month in early 2009, particularly affecting rural communities. For three summer months in 2010-11, heavy rains brought extensive flooding to Queensland, compounded by damage from Cyclone Yasi. Meanwhile, since September 2010, New Zealand has been faced with a series of seismic events in the Canterbury region, including a severe earthquake on 22 February 2011. All three disasters were followed by large-scale government responses.

Table 19.1 Scale of Disasters

\begin{tabular}{|l|l|l|l|}
\hline & Killed & $\begin{array}{l}\text { Estimated damage } \\
\text { (US\$billion) }\end{array}$ & $\begin{array}{l}\text { Affected } \\
\text { people }\end{array}$ \\
\hline Victorian bushfires & 173 & $1.3(0.1 \%$ of GDP) & 9954 \\
\hline Queensland floods & 35 & $15.9(1.1 \%$ of GDP $)$ & 200000 \\
\hline Canterbury earthquakes & 185 & $16.5(9.8 \%$ of GDP) & 301500 \\
\hline
\end{tabular}

Note A: CRED defines estimated damage as direct (for example, damage to infrastructure, crops, housing) and indirect (for example, loss of revenue, unemployment and market destabilisation).

Sources: Centre for Research on the Epidemiology of Disasters (CRED). n.d. <www.cred.be>; International Monetary Fund (IMF). 2011. Australia: Article IV Consultation. Country Report No.11/300, June; World Bank 2011, Queensland: Recovery and Reconstruction in the Aftermath of the 2010/2011 Flood Events and Cyclone Yasi (Washington, DC: The World Bank); Victorian Bushfire Reconstruction and Recovery Authority (VBRRA) 2011, Legacy Report (Melbourne: Victorian Bushfire Reconstruction and Recovery Authority).

\section{Australia}

Australia's State governments are responsible for emergency services, public schools, infrastructure and policing. The Commonwealth Government collects the most significant source of public revenue: direct taxes. State revenue largely comprises other taxes, particularly property taxes. State expenditures are far larger than revenue, resulting in high levels of fiscal imbalance, compensated by large grants from the Federal Government.

Federal and State governments negotiate funding arrangements after disasters. The National Disaster Relief and Recovery Arrangements (NDRRA) specify four funding categories of emergency assistance. These are individual relief (Category A), restoration of public assets (Category B), a community recovery package (Category $\mathrm{C}$ ) and acts of relief or recovery that alleviate damage in 'exceptional' circumstances (Category D). Federal assistance is dependent on the scale of the fiscal cost of relief. For Categories A, B and C, if the first threshold is passed the Commonwealth provides 50 per cent of State expenditure. ${ }^{2}$ For

2 That is, 0.225 per cent of the State's total general government sector revenue and grants in the financial year two years prior to the relevant financial year. 
expenditure exceeding the second threshold, the Commonwealth provides 75 per cent in excess of the second threshold. ${ }^{3}$ For Category D, the Commonwealth has discretion over the rate of its assistance.

The Australian Emergency Management Handbook Series includes a book on 'Community Recovery'. Community recovery focuses on five environments: social, built, economic, financial and natural. It argues that successful recovery is dependent on understanding the context, recognising complexity, using community-led approaches, ensuring coordination of all activities, employing effective communication and acknowledging capacity limits.

\section{Victoria}

Bushfires quickly spread and rapidly intensified, devastating several communities across Victoria on 7 February 2009. Worst affected were the towns of Kinglake and Marysville, both in Murrindindi Shire. With 173 deaths and 4300 buildings destroyed, it was the worst bushfire in Victorian history (VBRRA 2011).

By 10 February, the Victorian Government set up the Victorian Bushfire Reconstruction and Recovery Authority (VBRRA) to coordinate reconstruction. An order-in-council, a mechanism that lets the executive modify existing legislation, established the authority, which would act as a unit under the Department of Premier and Cabinet. The expected lifespan of the Victorian Bushfire Reconstruction and Recovery Authority (VBRRA) was not widely publicised, so as not to detract from the authority's work (VBRRA 2011). The authority was given broad terms of reference; policies were formed by a new, dedicated committee in the Victorian cabinet.

The authority's main function was to coordinate the Victorian Department of Human Services (DHS) and other Victorian service-delivery departments by delegating specific services under the recovery plan. The VBRRA worked with all levels of government: Commonwealth Government agencies, Victorian Government, local councils, especially the Murrindindi Shire Council, and nongovernmental organisations.

The early establishment of the VBRRA increased the tempo of recovery, but this advantage would have been lost if staffing requirements were not quickly satisfied. Fewer than 20 staff comprised the initial start-up team sourced from the Australian Defence Force (ADF) and Victorian Government departments. In March 2009, Christine Nixon, who had been the chief commissioner of Victoria Police during the time of the fires, became head of the VBRRA.

3 That is, 1.75 times the first threshold. 
Approximately $\mathrm{A} \$ 1$ billion was made immediately available for the recovery (Department of Treasury and Finance 2009). The Federal Government funded A \$266 million under the NDRRA, while private donations to the Victorian Bushfire Appeal Fund totalled A $\$ 395$ million (Victoria Bushfire Appeal Fund 2012). The total budget for the VBRRA over its life was A $\$ 21.2$ million, the majority going to Victoria's service-delivery agencies.

The strategic recovery framework was developed from both Australian and international experience. In line with best practice, the recovery plan focused on local communities, with four broad headings. The 'people' heading included rebuilding community assets, such as recreational facilities and halls, temporary housing and counselling. 'Reconstruction' involved community and Stateowned buildings, infrastructure and provision of building advice to residents. 'Economy' combined a number of support packages for business investment stimulus. 'Environment' aimed to restore the natural environment to its prebushfire condition, protect endangered animals and stabilise land.

The VBRRA (2011) cited evidence that community involvement could improve individual health and wellbeing. The authority conducted 29 community meetings, attended by approximately 4400 people. These meetings gave the authority legitimacy and established clear recovery requirements. The authority encouraged the formation of community groups, Community Recovery Committees (CRCs), to develop recovery plans for their areas. While the VBRRA would provide guidance and templates for CRC planning, CRCs established priorities and wrote recovery plans, which the VBRRA combined into a Statewide recovery plan. Nearly 800 CRC projects were funded.

The rebuilding of Marysville showcases the recovery process undertaken in Victoria (VBRRA 2009). The Victorian Bushfire Appeal Fund disbursed A $\$ 29$ million in grants to Marysville within eight months. Temporary housing was built for the local community, while a Rebuilding Advisory Centre provided advice to residents on rebuilding homes. Residential reconstruction was accelerated by the Victorian Government's amendment of the Victorian Building Regulations so destroyed homes could be rebuilt without planning permits. The residential building standards were changed so new structures could withstand a severe bushfire event. A temporary marketplace provided businesses with interim trading facilities. Around 600 people contributed to the town's Urban Design Framework, identifying immediate needs such as regenerating commerce and locating a petrol station, and 'catalyst projects' that would stimulate economic recovery.

After 7 February, the Premier of Victoria announced the formation of a royal commission to investigate the causes of and immediate response to the disaster. The commission's terms of reference required it to improve the resilience of Victoria to future bushfire events. It was chaired by Bernard Teague, a former 
judge of the Supreme Court of Victoria. On 31 July 2010, the commission delivered its final report, with 67 recommendations. They spanned Victorian bushfire safety policy, emergency management and fireground response, to planning and building, land management and the organisation of fire services. These recommendations affected State institutions (for example, the Country Fire Authority) and State regulations, and access to Commonwealth resources (for example, aerial resources owned by Emergency Management Australia and the Department of Defence). In areas of high fire risk, the commission recommended a 'retreat and resettlement' plan for affected communities.

A pressing issue was the distribution of donations received through the relief effort. These funds were distributed through DHS at the direction of an independent advisory panel; however, there was no consensus on whether the uninsured should receive more from the fund than insured homeowners. Some insured homeowners questioned whether the uninsured deserved greater pity. One argued, 'I think we should all get the same'.

Insurance status did not affect fund payout eligibility for damaged and destroyed homes; however, payouts were partially dependent on the circumstances of the applicant. For destroyed homes and contents, payouts were a maximum of $\mathrm{A} \$ 45000$, with an additional $\mathrm{A} \$ 40000$ depending on need. For damaged homes, payouts were a maximum of $\mathrm{A} \$ 35000$, of which $\mathrm{A} \$ 20000$ was based on need. Other payouts were available, such as transitional support, psychological support packages and support for exceptional hardship and severe injury.

The VBRRA was intended as a temporary institution to direct immediate recovery needs. The Victorian Government intended the authority's life to be approximately 18 months, but it was lengthened to two years. To plan for its closure, transition risks were identified, mitigation plans were put in place and it was ensured that permanent government departments could enact the recovery plan. One risk was the expiration of staffing contracts that might disrupt the work of the authority in its final months, but this was alleviated through staff retention and planned redeployment. The VBRRA was officially disbanded on 30 June 2011.

Prior to the VBRRA's closure, there were concerns that the pace of reconstruction was slow. Two years after 7 February, 41 per cent of homes had been rebuilt; some expected recovery to take up to five years. Stelling et al. (2011) conducted a number of interviews with informants and focus groups in the Beechworth region. Communities felt they had been brought together and their networks were strengthened after the fires; but they also believed that over time these bonds would weaken as community members left, and resentment stemming from some decisions taken during and after the fires lingered. Nevertheless, 
Future-Proofing the State

community resilience against future event appears to have been built. Participants in the study believed their communities were far better prepared for bushfire events than before 2009.

\section{Queensland}

In 2010, the Southern Oscillation climate pattern saw the strongest La Niña pattern since 1976, bringing above-normal wet weather to Queensland. Flooding began in December 2010 and increased on 23 December. Cyclone Tasha, a category one cyclone, brought further rain and damage on 24-25 December. By the end of the rains, more than 99 per cent of Queensland was declared 'disaster affected'. Cyclone Yasi, a category five cyclone, compounded flood damage in northern Queensland on 3 February 2011.

In 2006 Queensland had experience of recovering from meteorological disasters when Cyclone Larry caused A $\$ 1.5$ billion of damage in the north of the State. Recovery was steered by a task force, led by General Peter Cosgrove, former chief of the Australian Defence Force. General Cosgrove was also an internationally recognised logistics expert, whose arrival in the area instantly lifted morale. Recovery was generally successful.

The Disaster Management Act 2003 was amended in 2010 following a review of Queensland's disaster management arrangements (Government of Queensland 2011). The State Disaster Management Group (SMDG) is the key policy and decision-making body for Queensland's disaster management. Recovery required Statewide coordination and management of large resources. The amendments to the 2003 Act let the Queensland Government establish a designated recovery authority to prioritise agency response and recovery funding.

The initial change to institutional settings came soon after the December flooding, and was at first similar to the Victorian experience. The State Government established a Flood Recovery Taskforce and a special cabinet committee to coordinate responses. The task force was headed by Major General Mick Slater, then commander of the Australian 1st Division, in Brisbane. The choice of military leadership echoed Queensland's task force in the aftermath of Cyclone Larry, enabling transfer of operational lessons from that event.

Enabling legislation soon followed. On 21 February 2011, the task force was absorbed into a new statutory authority, the Queensland Reconstruction Authority (QldRA), with the passing of the Queensland Reconstruction Authority Act (QldRA Act). The QldRA had clear functions. It decided recovery priorities, worked closely with communities, collected information about property and infrastructure, shared data with all levels of government, coordinated and distributed financial assistance, and facilitated flood mitigation. 
The QldRA board comprised Major General Slater, two members nominated by the Australian Government, ${ }^{4}$ one nominated by the Local Government Association of Queensland ${ }^{5}$ and three with expertise and experience in engineering and planning. ${ }^{6}$ The authority's chief executive was Graeme Newton, formerly of Queensland Water Infrastructure. The board reported directly to the Premier of Queensland, Anna Bligh.

The QldRA estimated the rebuild cost at A\$6.8 billion (QldRA 2011a); 75 per cent would be provided by the Federal Government under the NDRRA and 25 per cent would come from the State Government. Road reconstruction took 70 per cent of the QldRA's budget, with the majority of the residual going to grants aimed at primary producers, small businesses and non-profit organisations. ${ }^{7}$ The QldRA reconstruction framework was based on six lines: human and social; economic; environmental; building recovery; roads and transport; community liaison and communication. Six subcommittees in these areas were established with unique concepts of operation.

The QldRA was directed by its enabling legislation to ensure 'Queensland and its communities effectively and efficiently recover from the impacts of disaster events' (QldRA 2011a:47). Its powers were broad, having power to acquire land, carry out works and implement development schemes for declared projects. It could also close roads, overrule council development decisions and decide the fate of damaged infrastructure.

The QldRA had recovery and reconstruction phases. Recovery would be completed by 30 June 2011 and reconstruction by the end of 2012 (Government of Queensland 2012). The QldRA's operations were to be transferred to other agencies after two years. ${ }^{8}$ The recovery effort made substantial progress in the first six months (see Table 19.2). Most of the work repaired damaged infrastructure, while the QldRA focused on the capability of affected areas to withstand future flooding by building resilience, improving damaged structures and incorporating local government in the rebuilding effort in all six reconstruction areas. More specific plans included storm tide-prone area reconstruction (QldRA 2011c) and improvements to electrical infrastructure (QldRA 2011d).

\footnotetext{
4 Brad Orgill, head of the Building the Education Revolution Implementation Taskforce, and Glenys Beauchamp, secretary of the Department of Regional Australia, Regional Development and Local Government. 5 Brian Guthrie, former CEO of Townsville City Council.

6 Kathy Hirschfeld, a former oil executive; Steve Golding, former director-general of Main Roads; and Jim McKnoulty, a local government planning expert.

7 Provided by the Queensland Rural Adjustment Authority (QRAA).

8 Section 139 of the QldRA Act.
} 
Future-Proofing the State

Table 19.2 Damage Impact and Recovery Statistics

\begin{tabular}{|c|c|c|}
\hline & $\begin{array}{l}\text { November } 2010-\text { March } \\
2011\end{array}$ & As at September 2011 \\
\hline Roads & $\begin{array}{l}9170 \mathrm{~km} \text { of Queensland's } \\
\text { road network affected }\end{array}$ & $\begin{array}{l}8482 \mathrm{~km} \text { of Queensland's } \\
\text { road network recovered }\end{array}$ \\
\hline Rail & $\begin{array}{l}4748 \mathrm{~km} \text { of Queensland's rail } \\
\text { network affected }\end{array}$ & $\begin{array}{l}4596 \mathrm{~km} \text { of Queensland's } \\
\text { rail network recovered }\end{array}$ \\
\hline Bridges and culverts & $\begin{array}{l}89 \text { State-owned bridges and } \\
\text { culverts with major damage }\end{array}$ & $\begin{array}{l}89 \text { State-owned bridges and } \\
\text { culverts recovered }\end{array}$ \\
\hline Schools & $\begin{array}{l}411 \text { Queensland schools } \\
\text { affected }\end{array}$ & $\begin{array}{l}411 \text { Queensland schools } \\
\text { operating }\end{array}$ \\
\hline National parks & $\begin{array}{l}138 \text { national parks closed due } \\
\text { to natural disaster }\end{array}$ & $\begin{array}{l}123 \text { national parks } \\
\text { reopened }\end{array}$ \\
\hline $\begin{array}{l}\text { Premier's Disaster } \\
\text { Relief Appeal }\end{array}$ & \multicolumn{2}{|c|}{$\begin{array}{l}\text { More than } A \$ 276 \mathrm{~m} \text { donated, with more than } A \$ 251 \mathrm{~m} \\
\text { distributed to individuals }\end{array}$} \\
\hline $\begin{array}{l}\text { Personal hardship and } \\
\text { assistance grants }\end{array}$ & \multicolumn{2}{|c|}{$\begin{array}{l}\text { More than } A \$ 121 \mathrm{~m} \text { in grants paid to small businesses, } \\
\text { primary producers and non-profit organisations. More than } \\
A \$ 12 \mathrm{~m} \text { in concessional loans to small businesses and } \\
\text { primary producers }\end{array}$} \\
\hline $\begin{array}{l}\text { Sport Flood Fight } \\
\text { Back Scheme }\end{array}$ & \multicolumn{2}{|c|}{$\begin{array}{l}\text { More than } \mathrm{A} \$ 13 \mathrm{~m} \text { in funding for infrastructure and/or } \\
\text { equipment to assist organisations to re-establish sport and } \\
\text { recreation services }\end{array}$} \\
\hline
\end{tabular}

Source: Adapted from QldRA (2011b).

The QldRA exercised its powers most visibly in reconstructing Grantham, a town west of Brisbane. Declaring it a 'reconstruction area' in April 2011, the authority created a 'development scheme' for the town, in consultation with local residents. ${ }^{9}$ The scheme enabled the QldRA to override planning instruments, plans and policies made under any Act. In May 2011, the Lockyer Valley Regional Council purchased 937 ha of land on higher ground and offered a 'swap deal' to Grantham residents. By December 2011, the Grantham Reconstruction Area was in effect, with the QldRA arguing the scheme would sweep away 'regulatory hurdles' that would otherwise hinder progress.

The flooding led to a significant rise in insurance premiums. One estimate suggested average home and contents premiums rose by 12 per cent, with floodaffected areas seeing average increases of up to 41 per cent (Insurance News 2011). Some homeowners were surprised to discover they were not covered for flood damage. Because insurers lacked a common definition of a flood event, the Federal Government subsequently mandated a standard definition for flooding for all insurance policies.

The Federal Government provided approximately A\$5 billion of the reconstruction fund, some 50 per cent of the total, imposing a flood levy on individuals with incomes of more than $\mathrm{A} \$ 50$ 000. One senator cited moral

9 Per sections $62-5$ of its enabling legislation. 
hazard as a reason for initially withholding his support because the Queensland Government's insurance fund did not have reinsurance. His eventual support was conditional on mandatory insurance for State governments against disasters and States losing access to NDRRA funding if insurance cover for State assets was deemed inadequate.

In June 2011, the World Bank (2011) reported on the Queensland reconstruction effort, concluding that it met many good-practice standards, while commending the QldRA on its 'build back better' focus. It argued that the response saved lives, quickly provided funding to individuals and communities, and management of the recovery and reconstruction was effective.

\section{New Zealand}

New Zealand has two institutions designed to deal automatically with disaster recovery. First, the Earthquake Commission (EQC), a crown entity, provides partial insurance for natural disasters. The EQC is funded by levies on home insurance and purchases cover with reinsurance companies. After a natural disaster, the EQC pays out the first $\mathrm{NZ} \$ 100000^{10}$ of damage suffered on insured houses, with private insurers covering the residual. ${ }^{11}$ Prior to the first Canterbury earthquake, the EQC's assets were approximately NZ\$6 billion (EQC 2010). Second, Civil Defence and Emergency Management (CDEM), a ministry, coordinates the initial response after a state of emergency is declared.

CDEM can declare two types of emergency. A local emergency empowers only subsidiary groups in the affected area to respond. A national emergency provides response powers to all CDEM groups simultaneously, and was not used before 2010 .

The first Canterbury earthquake struck at 4:35 am on 4 September 2010. It was New Zealand's most damaging earthquake since the 1931 Napier earthquake, but caused no reported deaths because the Christchurch city centre was largely deserted. A local emergency was then declared. The event caused damage of approximately NZ\$5 billion. Insured homeowners were eligible to lodge damage claims with the EQC immediately.

Fears that existing legislation would slow the recovery process encouraged the Government to expand its powers. The Government faced few constraints on its capacity to amend legislation or intervene in the affairs of specific localities. A local MP, Gerry Brownlee, was appointed Minister for Earthquake Recovery. Within two weeks, legislation was passed in the form of the Canterbury

10 Plus goods and services tax.

11 The EQC's cover does not apply to businesses. 
Earthquake Response and Recovery (CERR) Act. It provided for orders-incouncil for the recovery. Brownlee argued this power was necessary to remove bureaucracy and speed up the recovery process.

On 14 September 2010, the Canterbury Earthquake Recovery Commission (CERC) was established under the Act to enable better coordination between local and central governments. CERC advised on potential orders-in-council to the minister. CERC had seven commissioners, three of whom were the mayors of Christchurch City, Selwyn District and Waimakariri District; one was from Environment Canterbury, the regional authority, and three were appointed by the minister. CERC's life was limited to about 18 months, after which it would disband and orders-in-council applying to Canterbury would expire.

This response was severely challenged by the earthquake of 22 February 2011, resulting in 185 fatalities, most due to building collapses. The earthquake's proximity to the city caused more damage to buildings than the September earthquake and liquefaction damaged land to a far greater extent. ${ }^{12}$ Consequently, the Civil Defence Minister declared a national state of emergency. The second earthquake scaled up the challenge facing the Government. The EQC determined that the February earthquake was a new event, ${ }^{13}$ enabling homeowners to claim against new damage suffered. The Government set aside an additional NZ\$5.5 billion for reconstruction costs as part of the 2011 budget.

Because the orders-in-council were scheduled to expire in April 2012, the CERR Act was replaced with the Canterbury Earthquake Recovery (CER) Act. This legislation provided much wider and more significant powers. The Act and associated orders-in-council extended the period in force to 2016 and the Minister for Earthquake Recovery was empowered to 'suspend, amend or revoke' a number of local council plans and 'suspend or cancel' resource consents granted under the Resource Management Act. These powers enabled a recovery strategy to be developed by November 2011 in conjunction with Christchurch City Council, Selwyn and Waimakariri District Councils and Environment Canterbury.

The most important change was the establishment of a new government department: the Canterbury Earthquake Recovery Authority (CERA). The Act gave CERA strong powers and a budget of NZ\$25.5 million for the first two years. Roger Sutton, previously chief executive of a regional electricity distribution company, was appointed to head the authority. ${ }^{14}$ CERA decided reconstruction

\footnotetext{
12 Liquefaction is the surfacing of liquefied sand and water from below the ground due to shaking during an earthquake.

13 Prior to the February earthquake, there had been four such 'new events' including the initial September earthquake.

14 CERA was immediately active, with deputy State Service commissioner John Ombler as acting chief executive.
} 
priorities, expropriated land with compensation, entered premises with notice to undertake works and closed roads. It also used its power to demolish and dispose of buildings.

The authority took control of public works from CDEM on the expiration of the national state of emergency on 1 May 2011. CERA coordinated the drafting of the recovery strategy for Greater Christchurch, which complemented Christchurch City Council's draft recovery plan for the CBD. The recovery strategy, released in October 2011, referred to 15 plans along four lines of reconstruction: economic, social, natural and buildings. Each plan would involve several stakeholders, including central and local government bodies, non-governmental organisations, such as the region's principal iwi, Ngāi Tahu, and business organisations.

Damaged housing was an immediate concern for CERA. Many residents questioned rebuilding on land that had suffered liquefaction. Geotechnical information needed refreshing after the earthquake. The risk of significant aftershocks deterred rebuilding in the short term and reluctance by insurance companies to offer new policies compounded the issue. CERA's response was to divide the city's land into several areas. Most areas were designated 'green', with lesser degrees of risk for future liquefaction, which allowed for rebuilding; however, land repair in 'red' areas would be 'prolonged and uneconomic'. The Crown would compensate residents in red areas for loss of their homes at the council's last valuation of their property. ${ }^{15}$

Continuing seismic activity seriously impeded recovery operations. After September 2010 the concentration of earthquakes shifted eastward, with several damaging more buildings. Liquefaction continued to cause problems near the Avon River, despite many areas being designated by CERA as suitable for rebuilding. By 8 February 2012, the EQC recognised 15 different events, allowing affected insurance holders to claim against new damage; however, the region has not suffered further damage comparable with that of the September 2010 or February 2011 earthquakes.

Seismic uncertainty depressed the supply of insurance, throttling quick home and business reconstruction. Alan Bollard and Mike Hannah (2011) argued that the CERA changes, land remediation and reassessment of damage on buildings complicated the insurance process, as geotechnical and policy uncertainties have discouraged insurers from increasing their exposure to Canterbury.

Excessive claims from the February 2011 earthquake resulted in one domestic provider, AMI, requiring nationalisation. Other insurers anticipated higher 
reinsurance costs, increased their premiums and sought to minimise exposure to the rebuild. Bad loans and the risk of business disruption created uncertainty for banks and other financial institutions.

The earthquakes placed immense pressure on the EQC's capacity. Additional claims by individuals were made as already damaged homes suffered more damage from aftershocks. Cowan and Simpson (2011) argue liability estimates and loss allocation were complex because no existing models were calibrated for events of this type and liability for land damage was difficult to estimate. Furthermore, the EQC had to meet complex legal requirements, and it coordinated more than a dozen agencies from the private sector and government to meet geotechnical demands. On 11 October 2011, the Government announced that the insurance levy used to finance the EQC would be tripled.

Monetary and fiscal policy responses were swift. The Reserve Bank of New Zealand (RBNZ) decreased its official cash rate by 50 basis points in the immediate aftermath of the February earthquake. Public finances were put under pressure by the earthquakes. Earthquake-related public expenditure was approximately NZ\$13.6 billion in the 2010-11 financial year ${ }^{16}$ (Bollard and Hannah 2011). The earthquakes coincided with increases in government debt stemming from the late 2000s economic downturn. In response, the Government has set a target of returning to budget surplus by 2015 .

The Government established a royal commission of inquiry to investigate buildings that caused injury on 22 February 2011, especially the CTV Building and PGC House, and those that failed after being deemed safe following the September 2010 earthquake. Furthermore, the Government is investigating the adequacy of current legal and best-practice requirements. In October 2011, an interim report with geotechnical and building design recommendations was released, and the final report was due for release in late 2012.

After the November 2011 general election, the National Party formed a coalition government with several minor parties. CERA compiled a Briefing to the Incoming Minister summarising the recovery process and future challenges. It identified seismic uncertainty as a major issue in recovery of the CBD and the primary cause of landowners delaying decisions to repair or rebuild. It acknowledged that 'managing the pace and timing of its contribution to the recovery is the single greatest risk CERA faces' (CERA 2011). It also noted that CERA's work program might require increased future funding and defended the recovery process to date, arguing that economic activity and employment were above expectations and that the foundation was set for recovery.

16 Year ended 30 June 2011. 


\section{Discussion}

The three cases show points of similarity and difference. While each government created recovery agencies to coordinate the recovery, they had different functions and powers. They were tasked with community engagement yet citizens were empowered to make decisions to different degrees. The cases display clear evidence of institutional learning as recovery progressed and the complexity of insurance issues after disaster.

\section{Choice of Agency Type}

The recovery agency in Victoria was not complemented with legislative powers, an apparently deliberate strategic decision that let the Government coordinate recovery quickly. The bushfires took place over a relatively short period compared with the disasters in Queensland and Canterbury. The marginal benefits of waiting for new legislation to be drafted, passed and enacted justified the immediate establishment of a recovery authority. It is also clear that there was considerable goodwill for the VBRRA in the initial stages of recovery. In contrast, Queensland and Canterbury experienced repeated events that exhausted the institutions initially set up to cope with them. Recovery authorities with more and greater powers were deemed necessary in those cases.

Queensland and New Zealand designed recovery authorities with strong powers that circumvented existing regulations. Queensland's institutional response was specifically cited in a New Zealand cabinet minute proposing the creation of CERA. The agencies' powers are remarkably similar, but there are important differences. CERA is a government department while the QldRA was created as a statutory body. The QldRA had a board and its minister was the premier rather than a portfolio minister. In New Zealand, Brownlee had the advantage of being a senior minister in cabinet, indicating more direct control and influence over the recovery process.

Although both agencies faced big challenges, they faced very different issues. With the exception of small towns, the QldRA's funding was primarily focused on the restoration of services and rebuilding infrastructure, while respecting established use of premises. Christchurch, facing more complex recovery demands, granted authority to the Minister for Earthquake Recovery to change resource consents granted under the Resource Management Act.

An effective command structure requires leadership capable of rapport with the affected community. All three cases reveal a similar preference. An outstanding example for the Australian responses to draw on was the Queensland Government's appointment of General Cosgrove, former chief of the 
ADF, to lead its response to Cyclone Larry in 2006. In 2011, the Queensland Government appointed high-level ADF officers to head recovery coordination. Military involvement signals an effective response to a traumatised community and managing the logistics of recovery. In Victoria the appointment of a public figure gave the VBRRA significant capital, which was important given the lack of enabling legislation. In New Zealand, Roger Sutton became a high-profile figure in the immediate response phase.

\section{Community Engagement}

All three approaches involve the public in decision-making; yet public participation does not always diffuse power from government to citizens. Arnstein's (1969) ladder of citizen participation describes eight 'rungs', ranging from non-participation to 'citizen power'. In Hirschman's (1970) framework of 'exit, voice and loyalty', participation that does not empower citizens may lead them to exit the process, impoverishing decision-makers' information base.

The VBRRA acknowledged that community-led recovery was difficult when individuals were still undergoing personal recovery, and it was not until later that the model changed from 'token' consultation to creating partnerships with CRCs. The VBRRA adopted most of the projects identified and prioritised by CRCs.

In New Zealand, the CER Act mandates the minister to appoint a community forum and 'have regard' to their information and advice. This has not been sufficient to build consensus on complex issues in Christchurch. Ostrom (1986) outlines a consultative institutional model with several rules under which the participatory game is played. When authority rules constrain decision-makers, a more effective process is likely. Merely having regard to a forum's information and advice concentrates power with the central government. Boundary rules specify how participants are selected. Unlike Victoria, where the membership of CRCs was self-selecting, Christchurch's sole community forum, with only 38 members, was appointed by the minister. The pay-off rules distribute cost and benefits to participants. The draft CERA recovery plan for Greater Christchurch received 304 submissions and it is unclear if it was influenced by other means of community participation. Community forum minutes record that participants reported an 'attitudinal problem' within Christchurch City Council that left them feeling disempowered (CERA 2011).

It is unclear if the participatory process has built consensus. Hisschemoller and Hoppe (1996) describe a lack of consensus on knowledge, norms and values as an intractable controversy. Controversies come into existence if viewpoints of certain groups or interests are not taken seriously by policymakers (1996:49). They become serious if there is considerable policy and geotechnical uncertainty. 
Community engagement was mandated in the CER Act to develop the recovery plan for Greater Christchurch. It is unlikely that the time frame was sufficient to build consensus on some of the more complex issues facing the region.

Queensland's Grantham land swap was also contentious. Some residents preferred to remain in the flooded valley despite the known risks; however, residents were not compelled to accept the deal offered by the Lockyer Valley Regional Council. In Christchurch, issues were acute when compulsion was used. This ranged from dissatisfaction over building restrictions to unhappiness with the land zoning of homes. Such intractable controversies are a serious obstacle that New Zealand has yet to overcome.

\section{Institutional Learning and Adaptive Change of Rules}

The VBRRA Legacy Report (2011) outlines a number of lessons arising from the authority's operations. Aligning the recovery body with the highest level of government provides authority. Statutory powers can speed up progress on unanticipated issues, especially if they cannot use other government agencies' existing powers. Broad terms of reference, though necessary in complex recovery situations, generate uncertainty. The recovery body must be flexible as recovery moves from immediate issues towards more enduring, long-term issues.

The QldRA appeared to take on some of these lessons. First, the enabling legislation clearly defined its functions and gave it considerable powers. Second, its board reported directly to the Queensland premier. Third, the QldRA had clear steps to move from recovery to reconstruction before transitioning to other agencies. Permanent government agencies were involved in subcommittees in the six areas of reconstruction, and their priorities were decided by the QldRA.

Creating CERA was the clearest adaptation in New Zealand. Establishing the department outside Wellington indicated government recognition that in a crisis it is important to be close to the people affected. CERA (2011) made explicit note of lessons it had learned from local and international experience, including: building the capacity of the community-led response, devolving decisionmaking to the local level, focusing on those most affected by the disaster, and ensuring government agencies worked in a holistic, joined-up way.

\section{Insurance Issues and Building Resilience}

Moral hazard was a clear problem in Victoria and Queensland. In Victoria the high level of donations made distribution a complicated process. In the end, the uninsured did not receive special treatment, though increased need among those individuals may have led to greater access to funding. This approach has 
far less potential to distort individual incentives than alternatives. Queensland's floods highlighted moral hazard among intra-governmental actors, with the Federal Government resorting to compulsory State disaster insurance.

New Zealand's permanent disaster institutions adequately coped with the issue of moral hazard for home insurance. The EQC reduced risk exposure for private insurers without encouraging homeowners to neglect taking up insurance. The Government refused to extend the EQC's coverage to those without insurance and has not yet offered compensation for uninsured red-zoned land. It is not yet clear if moral hazard issues will result from the nationalisation of AMI. Nevertheless, the reduced supply of private insurance in the Canterbury region has slowed the pace of recovery.

All three cases show a clear commitment to mitigating the risk of future disasters. Inquiries investigated the causes of and response to the disaster, the failure of buildings and infrastructure, and delivered recommendations to reduce the risk of reoccurrence. Victorian building codes were strengthened and the capacity of standing institutions for disaster response was increased. Queensland's issues relating to flood preparedness were delivered quickly. In New Zealand, the royal commission's interim report delivered recommendations that informed early decision-making on rebuilding and repair work in Christchurch.

\section{Conclusion}

Despite differences in the three approaches to disaster recovery there are similarities. Institutional responses dealt with the disaster effectively and quickly, and avoided the feedback loop between poor institutions and higher crisis levels. While it is too early to judge the success of the recovery effort in Christchurch, large-scale unemployment, homelessness and poverty have been avoided. Despite parts of the CBD remaining closed to the general public, Christchurch continues to function relatively well.

In its evaluation of the Queensland recovery effort, the World Bank (2011) highlighted a number of features important in good recovery practice. First, the recovery effort built on planned responses to disaster. Second, governments introduced specific agencies to deal with recovery. Third, they showed a commitment to community engagement, particularly in longer-term strategic planning. Fourth, all worked with local government in recovery planning. Fifth, relief and recovery arrangements were already in place, with the World Bank specifically citing the NDRRA. Sixth, the recovery effort attempted to ensure that mitigation of risk was incentivised and moral hazard was avoided. Seventh, technical advice was provided to individuals trying to rebuild. Eighth, efforts 
were made to understand policy failures that exacerbated the disaster, and to recommend changes to mitigate future risk. Many of these good-practice principles are also evident in the Victorian and Canterbury recovery efforts.

Successful institutions are constrained by their context, ever changing in a crisis situation. Governments showed an ability to learn from past experiences and as the recovery process moved ahead. Where institutions, both public and private, struggle to cope with the demands disasters impose on their capacity, it is important that these institutions are supported to maintain the tempo of recovery. Optimising the level of resources that are used in recovery and reconstruction is hard, and an under-resourced recovery can create new problems that last for years after the disaster. Early engagement and ensuring that the demands on government are kept to a manageable level are the clearest lessons of the three cases.

\section{References}

Arnstein, S. 1969. 'A Ladder of Citizen Participation', AIP Journal, 35(4):216-24.

Birkland, T. A. 1997. After Disaster: Agenda Setting, Public Policy and Focusing Events (Washington, DC: Georgetown University Press).

Birkland, T. A. 2006. Lessons of Disaster: Policy Change after Catastrophic Events (Washington, DC: Georgetown University Press).

Bollard, A. and Hannah, M. 2011. Tale of two crises, Speech to Canterbury Employers' Chamber of Commerce, Christchurch. Available from: <http:// www.rbnz.govt.nz/speeches/4659119.html>.

Bovens, M. 2007. 'Public Accountability', in E. Ferlie, L. E. Lynn and C. Pollitt (eds) The Oxford Handbook of Public Administration (Oxford: Oxford University Press).

Buchanan, J. M. 1975. 'The Samaritan's Dilemma', in E. Phelps (ed.) Altruism, Morality and Economic Theory (New York: Russell Sage Foundation).

Canterbury Earthquake Recovery Authority (CERA). 2011. Briefing to the Incoming Minister, December (Christchurch: Canterbury Earthquake Recovery Authority). Available from: <http://cera.govt.nz/about-cera/briefing-for-incoming-minister $>$.

Carvallo, E., Galiani, S., Noy, I. and Pantano, J. 2011. Catastrophic Natural Disasters and Economic Growth, IDB WP Series No. IDB-WP-183(Washington, DC: Inter-American Development Bank).

Centre for Research on the Epidemiology of Disasters (CRED). n.d. <www.cred.be>. 
Coffman, M. and Noy, I. 2009. A Hurricane's Long-Term Economic Impact: The Case of Hawaii's Iniki, Working Paper No. 09-5, June (Manoa: Department of Economics, University of Hawai'i). Available from: <http://www.economics. hawaii.edu/research/workingpapers/workingpapers.html $>$.

Cowan, H. and Simpson, I. 2011. Planning for disasters and responding to unforeseen complexity: the first large test for the New Zealand Earthquake Commission, 12th Hazards Conference, 29 September - 1 October, Surfers Paradise, Qld.

Department of Treasury and Finance. 2009. 2009 State Budget: Building jobs, Building Victoria, 5 May (Melbourne: Government of Victoria). Available from: <http://www. budget.vic.gov.au/domino/Web_Notes/budgets/budget09.nsf/d6e571e551bef80eca 2572bb002bcea7/5d0390e6678ff38fca2575ac00574fd5!OpenDocument $>$.

Earthquake Commission (EQC). 2011. Earthquake Commission Annual Report 2009-2010 (Wellington: Earthquake Commission).

Folke, C., Colding, J. and Berkes, F. 2003. Synthesis: Building Resilience and Adaptive Capacity in Social-Ecological Systems (Cambridge: Cambridge University Press).

Government of Queensland. 2011. Disaster Readiness Update, November (Brisbane: Department of the Premier and Cabinet). Available from: <http:// www.premiers.qld.gov.au/publications/categories/reports/assets/disasterreadiness-update.pdf $>$.

Government of Queensland. 2012. Complete Budget Paper 5-Service Delivery Statements (Brisbane: Government of Queensland). Available from: <http:// www.budget.qld.gov.au/budget-papers/2011-12/bp5-2011-12.pdf $>$.

Hirschman, A. O. 1970. Exit, Voice and Loyalty: Responses to Decline in Firms, Organisations, and States (Cambridge, Mass.: Harvard University Press).

Hisschemoller, M. and Hoppe, R. 1996. 'Coping with Intractable Controversies: The Case for Problem Structuring in Policy Design and Analysis', Knowledge and Policy, 8(4):40-60.

Insurance News. 2011. 'Queensland Sees Highest Rise in Residential Premiums', Insurance News, 24 October. Available from: <http://www.insurancenews. com.au/local/queensland-sees-highest-rise-in-residential-premiums $>$.

International Monetary Fund (IMF). 2011. Australia: Article IV Consultation. Country Report No.11/300, June.

Kousky, C. and Cooke, R. M. 2009. Climate Change and Risk Management: Challenges for Insurance, Adaptation and Loss Estimation, RFF Discussion Paper No. 09-03-REV (Washington, DC: Resources for the Future). 
Noy, I. 2009. 'The Macroeconomic Consequences of Disasters', Journal of Development Economics, 88:221-31.

Ostrom, E. 1986. 'An Agenda for the Study of Institutions', Public Choice, 48(1):3-35.

Queensland Reconstruction Authority (QldRA). 2011a. Operation Queenslander: The State Community, Economic and Environmental Recovery and Reconstruction Implementation Plan 2011-2013 (Brisbane: Queensland Reconstruction Authority).

Queensland Reconstruction Authority (QldRA). 2011b. Rebuilding a Stronger, More Resilient Queensland (Brisbane: Queensland Reconstruction Authority).

Queensland Reconstruction Authority (QldRA). 2011c. Planning for a Stronger, More Resilient North Queensland. Part 1-Rebuilding in Storm Tide Prone Areas: Tully Heads and Hull Heads (Brisbane: Queensland Reconstruction Authority.

Queensland Reconstruction Authority (QldRA). 2011d. Planning for a Stronger, More Resilient Electrical Infrastructure. Improving the Resilience of Electrical Infrastructure during Flooding and Cyclones (Brisbane: Queensland Reconstruction Authority).

Skidmore, M. and Toya, H. 2002. 'Do Natural Disasters Promote Long-Run Growth?', Economic Inquiry, 40(4):664-87.

Stelling, A., Millar, J., Boon, H., Cottrell, A., King, D. and Stevenson, B. 2011. Recovery from Natural Disasters: Community Experiences of Bushfires in North East Victoria 2003 to 2009, ILWS Report No. 65 (Albury, NSW: Institute for Land, Water and Society, Charles Sturt University). Available from: <http://www.riv. csu.edu.au/research/ilws/research/reports/docs/65_Bushfire_Recovery.pdf $>$.

Victoria Bushfire Appeal Fund. 2012. December 2012 Progress Report (Melbourne: Department of Human Services). Available from: < http://www.dhs.vic.gov. au/_data/assets/pdf_file/0017/760220/VBAF-December-2012-Report.pdf $>$.

Victorian Bushfire Reconstruction and Recovery Authority (VBRRA). 2009. Rebuilding Marysville \& Triangle (Melbourne: Victorian Bushfire Reconstruction and Recovery Authority).

Victorian Bushfire Reconstruction and Recovery Authority (VBRRA). 2011. Legacy Report (Melbourne: Victorian Bushfire Reconstruction and Recovery Authority).

World Bank. 2011. Queensland: Recovery and Reconstruction in the Aftermath of the 2010/2011 Flood Events and Cyclone Yasi (Washington, DC: The World Bank). 
This text taken from Future-Proofing the State: Managing Risks, Responding to Crises and Building Resilience, edited by Jonathan Boston, John Wanna, Vic Lipski and Justin Pritchard, published May 2014 by ANU Press, The Australian National University, Canberra, Australia. 